\title{
Dlaczego ewolucja stworzyła myślenie?
}

P. Gärdenfors, Jak Homo stał się sapiens. O ewolucji myślenia, tłum. Tomasz Pańkowski, Czarna Owca, Warszawa 2010, ss. 328.

Prezentowana recenzja dotyczy książki pt. Jak Homo stat się sapiens. O ewolucji myślenia. Jej autorem jest Peter Gärdenfors - szwedzki profesor nauk kognitywnych na uniwersytecie w Lundzie, członek Królewskiej Akademii Literatury, Historii i Zabytków, a także Królewskiej Akademii Nauk. Peter Gärdenfors cieszy się międzynarodowym uznaniem jako znakomity filozof i członek organizacji zrzeszających najwybitniejszych szwedzkich naukowców. Recenzowana przeze mnie książka powstała w ramach projektu „Rewolucja poznawcza”, prowadzonego przez Instytut Futurologii (Institutet för Framtidsstudier).

Na początek kilka słów o celu książki. Autor określa go następująco: „Głównym celem tej książki jest opowiedzenie - jak najzwięźlej - historii wykształcenia się umiejętności myślenia cechującej współczesnego człowieka"1. Moim zdaniem, autor osiągnął ten cel, co więcej, uczynił to w bardzo dobrym stylu.

Peter Gärdenfors podchodzi do poruszanej przez siebie tematyki z należną pokorą. Zdaje sobie sprawę, że stoi przed bardzo trudnym zadaniem, ponieważ historia ewolucji myślenia nie pozostawia za sobą bezpośrednich śladów. Poza tym, ma on świadomość, że jego teoria nie jest jedyną słuszną, po prostu przyjmuje ją za najbardziej prawdopodobną. Jego postawa pokornego naukowca, przejawia się także w ostrożnym podejściu do niektórych tematów, gdzie używa on sformułowań typu : ,najprawdopodobniej”, „wydaje się, że".

1 P. Gärdenfors, Jak Homo stał się sapiens. O ewolucji myślenia, Czarna Owca, Warszawa 2010, s. 20. 
Książka podzielona została na rozdziały, te zaś na podrozdziały. Następujące po sobie części dotyczą odmiennych kwestii, lecz nawiązują do poprzednich i bazują na pojęciach, które zostały wcześniej wprowadzone, dzięki czemu podział książki jest logiczny i zasadny.

Plusem pozycji jest jej strona typograficzna - książka jest przejrzysta i estetyczna, formatowanie tekstu spójne, dość minimalistyczne. Tekst urozmaicony został rysunkami, które utrzymane są w tej samej konwencji, jak cała książka.

Autor, aby przybliżyć czytelnikowi swoją filozoficzną teorię, najpierw wprowadza go w świat ewolucji. Pierwszy rozdział: „Myślenie z perspektywy ewolucyjnej", służy przybliżeniu czytelnikowi kilku faktów na temat ewolucji: autor przedstawia drzewo genealogiczne człowieka i opisuje pierwsze gatunki hominidów. W rozdziale tym analizuje także, wraz z krótkim komentarzem, części składowe procesu myślenia, źródła dowodów empirycznych (dotyczących ewolucji myślenia) oraz wczesne stadia rozwoju myślenia. W ten sposób wprowadza czytelnika w omawianą tematykę oraz przygotowuje go do przyjęcia filozoficznych treści, które chce mu przekazać. W następnych dwóch rozdziałach autor omawia pojęcia takie jak: wrażenia, percepcja, wyobrażenie, świat wewnętrzny, bez znajomości których, czytelnik nie byłby w stanie zrozumieć jego teorii. W czwartym rozdziale: „Czytanie cudzych myśli”, opisuje zjawisko rozumienia przez małpy człekokształtne i ludzi myśli innych osobników. W piątym pisze o samoświadomości. Trzy ostatnie rozdziały dotyczą mowy i języka pisanego, które są efektem rozwiniętego świata wewnętrznego, są najwyższym etapem w rozwoju myślenia.

Autor zatem stopniowo przedstawia czytelnikowi swoją teorię ewolucji ludzkiego myślenia. Zaczyna od najbardziej prymitywnych form myślenia, a potem sukcesywnie wprowadza go w świat reprezentacji, światów wewnętrznych, istot gregoriańskich. Systematyczne przedstawienie zagadnienia z pewnością ułatwia jego zrozumienie nawet odbiorcy, który wcześniej nie miał styczności z 
tą tematyką. Tym bardziej, że każde nowe pojęcie, wprowadzane przez autora, zostaje dokładnie objaśnione i poparte przykładami.

Owe przykłady są dużą zaletą książki. Pochodzą z różnych dziedzin nauki, a dotyczą niemalże każdego z omawianych zagadnień. Uwiarygodniają poglądy autora, ale także zaciekawiają czytelnika. Przykłady doświadczeń - z małpami, które rozpoznawały własne odbicie w lustrze czy małymi dziećmi, które uczono, że nagroda spotyka je za wskazanie, spośród pustego i pełnego cukierków pudełka, pierwszego z nich - przyciągają uwagę i zastanawiają. Tym bardziej, że wyniki lub wnioski, które autor wyciąga, są niejednokrotnie zaskakujące, nieintuicyjne. Ponadto Gärdenfors podaje różnego rodzaju ciekawostki biologiczne, np. związane z budową ludzkiej krtani. Przykładów w całej książce jest bardzo wiele - niekiedy jednak właśnie przez ich zagęszczenie, tracą na jakości i nie są wystarczająco dogłębnie opisane, czy raczej nie zostają wyciągnięte z nich wyczerpujące wnioski. Sa to jednak rzadkie przypadki.

Autor często odnosi się do naszego codziennego życia. Na przykład: człowiek posiada umiejętność planowania. Bierze się ona stąd, że potrafi przewidywać, co zdarzy się w przyszłości, ma poczucie nadchodzących zdarzeń. Dlatego nie zawsze jest on szczęśliwy w danej chwili, mimo że „teraz” nic mu do szczęścia nie brakuje. Dzieje się tak ponieważ: „,szczęśliwi jesteśmy wówczas, gdy obecne i przyszłe pragnienia idą ze sobą w parze" ${ }^{2}$. Zatem zachodzi tu konflikt pomiędzy życiem teraźniejszym a myśleniem o przyszłości. Przez tego typu odniesienia, podobnie jak przez częste przykłady książka staje się bliższa czytelnikowi, ciekawsza.

Doświadczenia, które opisywane są w przykładach, przeprowadzane były przez naukowców z różnych dziedzin. W wielu przypadkach autor nie czerpie ich jednak bezpośrednio od nich, ale od filozofów, którzy - podobnie jak on - zajmowali się ludzkim myśleniem i jego ewolucją. Co więcej, tezy, które stawia autor, są nie tylko jego osobistymi refleksjami, ale syntezą poglądów, badań i eksperymentów, które na pierwszy rzut oka nie tak łatwo dają

2 Tamże, s. 122. 
się połączyć w spójną całość. W tekście znajduje się wiele odniesień do naukowców zajmujących się podobną tematyką. Książka ma w związku z tym bardzo bogatą bibliografię. Czasami jednak autor przedstawia poglądy kilku naukowców równolegle w sposób mało czytelny, co może powodować brak jasności przekazywanych treści.

Kolejną zaletą książki jest duża liczba cytatów. Są to nie tylko wypowiedzi naukowców, którzy badali ewolucję myślenia czy zachowania zwierząt, ale także poetów i pisarzy. Znajdziemy w książce cytaty z takich dzieł jak: Pismo Święte ${ }^{3}$ czy Faust $^{4}$ i takich autorów jak: Terry Pratchett ${ }^{5}$, William Szekspir ${ }^{6}$, Leszek Kołakowski ${ }^{7}$ oraz wielu innych. Początek każdego rozdziału rozpoczyna cytat nawiązujący do treści danej części książki, obrazujący zainteresowanie artystów, pisarzy i filozofów problemami poruszanymi przez autora i ich niejednokrotnie słuszne intuicje dotyczące możliwych rozwiązań. Autor pokazuje szerokie spojrzenie, interdyscyplinarność i znajomość literatury, wzbudzając ciekawość czytelnika. Zdarzają się jednak cytaty bardzo zaskakujące, jak np. przytaczane fragmenty Kubusia Puchatka ${ }^{8}$, które przekazane są w dość żartobliwym tonie. Jednak w tym przypadku, paradoksalnie, żart ten można odczytać jako trafny i na poziomie.

Książka zawiera więcej humorystycznych fragmentów. Autor wprowadza w pierwszym rozdziale postać Egona, małpki rezusa, którego - jak zaznacza we wstępie - kupił sobie, aby móc lepiej przyjrzeć się zachowaniom tych zwierząt, a który - wbrew zapewnieniom naukowców (a także samego autora), że to niemożliwe potrafi mówić. Egon towarzyszy autorowi w trakcie pisania książki. Zadaje mu pytania, często czegoś nie rozumie, czyni ironiczne uwagi odnośnie jego osoby czy metody pracy, czasem śpi, drapie się po

\footnotetext{
3 Tamże, s. 200.

4 Tamże, s. 121.

5 Tamże, s. 87.

6 Tamże, s. 80.

7 Tamże, s. 188.

8 Tamże, ss. 168, 175.
} 
głowie, łupie orzeszki. Jest to postać, która swoim zachowaniem zaprzecza wszystkiemu, co autor pisze. Oczywiście jest to pewnego rodzaju zabieg narracyjny. Tego, na czym on dokładnie polega, czytelnik dowie się jednak dopiero pod koniec narracji, zanim to jednak nastąpi, jest skazany na domysły.

Kiedy czytamy książkę poważanego profesora, budzi się bezrefleksyjne zaufanie dla autorytetu. Peter Gärdenfors pokazuje czytelnikowi, że to jest błąd i należy pozostać czujnym. Dopiero patrząc na całość, można docenić słuszność zabiegu wprowadzenia do narracji irytującej postaci Egona, która z jednej strony podważa zaufanie do autora, z drugiej strony jednak skłania do zadawania pytań, szukania odpowiedzi we własnym zakresie i z innych źródeł, co paradoksalnie prowadzi ostatecznie do przywrócenia kwestionowanego zaufania dla autora.

Recenzowana przeze mnie książka jest książką filozoficzną. Jednak, podczas lektury można momentami odnieść wrażenie, że jest jej bliżej do książki o tematyce biologicznej, ewolucyjnej. Autor konsekwentnie przyjmuje taką właśnie perspektywę patrzenia na człowieka. Jednak typowo filozoficznymi elementami są: odwoływanie się przez autora do poglądów innych filozofów oraz stawianie sobie przez niego podstawowego pytania filozofa: dlaczego? Na przykład: dlaczego powstały takie, a nie inne umiejętności? Odpowiedź jest często odpowiedzią z zakresu biologii, np. odpowiedź na pytanie o to, dlaczego ludzie pierwotni żyjący na sawannach tańczyli i śpiewali, a szympansy, żyjące w lasach nie? Jednak nie na każde pytanie może odpowiedzieć nauka, obserwacja zwierząt czy rozwijających się niemowląt. Autor takich pytań jednak nie stawia. W książce nie ma otwartych pytań bez odpowiedzi. Pytanie filozoficzne zostaje postawione tylko wówczas, gdy ma na nie gotową odpowiedź, w postaci stworzonej przez siebie teorii. Gärdenfors przedstawia kilka ciekawych, alternatywnych odpowiedzi na filozoficzne pytania - należy do nich np. odpowiedź na pytanie o istnienie przyczyn. Autor przedstawia tezę, że symulatory generujące naszą percepcję wytwarzają pojęcie przyczyny, aby uzu- 
pełnić nasz świat wewnętrzny o brakujące elementy, uczynić go bardziej spójnym. Dzięki takiemu zabiegowi dysponujemy znacznie doskonalszym mechanizmem planowania niż np. małpy, które o przyczynach zdarzeń nie maja pojęcia (oprócz przyczyn ich własnych działań). Dalej autor pisze o tym, że ,tendencja do doszukiwania się ukrytych mechanizmów jest w człowieku tak silna, że można mówić o pędzie do przyczynowości"9. Autor uważa, że ów pęd do przyczynowości spowodował, że tworzymy pojęcie szczęścia (np. jako przyczyny wygranej na loterii). Autor uważa, że być może także Bóg, został stworzony w naszych umysłach przez ten mechanizm, że jest wynikiem naszego pędu do szukania przyczyn w świecie.

Podsumowując, warto zadać sobie pytanie: do kogo właściwie książka Gärdenforsa jest skierowana? Autor nie posługuje się fachowymi pojęciami bez ich wyjaśniania, zatem czytelnik, który sięga po tę pozycję, nie musi być wcześniej zaznajomiony z poruszaną tematyką. Z drugiej strony książka nie jest tylko omówieniem istniejących już poglądów z filozofii umysłu, lecz przedstawia autorskie teorie Gärdenforsa, dlatego lektura ta będzie cenną również dla tych, którzy fachowo zajmują się tymi zagadnieniami. Zatem może po nią sięgnąć zarówno student filozofii, jak i innego kierunku, może to nie być student, może to być uczeń liceum, osoba pracujacca czy emeryt. Może to być zawodowy filozof, zawodowy biolog, lekarz, mechanik, sportowiec, słowem każdy, niezależnie od wykonywanego zawodu, każdy kto jest ciekawy świata, kogo nurtują pytania dotyczące jego samego, ale także ten, kto wymaga od informacji rzetelności, empirycznego sprawdzenia, naukowego potwierdzenia. To wszystko znaleźć można w Jak Homo stat się sapiens.

Joanna Sokołowska

9 Tamże, s. 74. 